\title{
Effects of Transplanting Dates and Insecticide Frequency in the Control of Thrips tabaci Lindeman (Thysanoptera:Thripidae) on Onion (Allium cepa L.) in Sokoto, Nigeria
}

\author{
N. D. Ibrahim (Corresponding author) \\ Department of Crop Science, Faculty of Agriculture \\ U.D.U., Sokoto, Nigeria \\ Tel: 234-080-3603-0932Ｅ-mail: dolegoronyo@yahoo.com \\ A. A. Adesiyun \\ Department of Crop Protection, Faculty of Agriculture \\ University of Ilorin, Ilorin, Nigeria \\ E-mail: yinkaadesiyun@yahoo.com
}

\begin{abstract}
Two factors, transplanting date and insecticide frequency were combined to evaluate their effects in reducing population of thrips and yield of onion. Transplanting was done at monthly interval from November through March, while spraying was done fortnightly, starting from three weeks after transplanting (WAT) to nine WAT $(3,5,7$ and 9) using knapsack sprayer at $18.67 \mathrm{~g}$ a.i./ha. Results showed that early transplanting done in November and December had fewer thrips than the subsequent ones. At 7 WAT, late transplanting made in February had up to 191 thrips/plant and $<1$ in the early transplants. First spray was effective in reducing thrips by about $76 \%$ and second and subsequent sprays were less effective. There was significant difference between treatments $(\mathrm{P}<0.05)$ in spray at $4,6,7,9$ and $10 \mathrm{WAT}$ and the bulb yield of onion. The yield showed that two sprays produced up to $52.53 \mathrm{t} / \mathrm{ha}$, nearly doubling the control plots with $31.6 \mathrm{t} / \mathrm{ha}$. November transplant produced up to $60 \mathrm{t} / \mathrm{h}$ a and December transplant $51.82 \mathrm{t} / \mathrm{h}$ in three-insecticide spray. The average weight of bulbs from plots with 2 sprays and control plots were $238 \mathrm{~g}$ and $155 \mathrm{~g}$, respectively.
\end{abstract}

Keywords: Bulb, Fortnightly, Lambda- $\lambda$, Transplanting, Spray

\section{Introduction}

\subsection{Importance of onion}

The common onion, Allium cepa $\mathrm{L}$. is a vegetable crop of commercial importance throughout the world. The crop ranks second in importance after tomato among the vegetables in Nigeria. It is grown mainly for its bulb, which is used almost daily in every home (Amans et al., 2000). The bulb onion is normally harvested at the start of the dormant period (Brice et al., 1997). Onion can be grown under a wide range of climatic conditions, but they do best in a mild climate without excessive rainfall or extreme temperature. They require cool, moist conditions for early growth, followed by warm, drier conditions for maturation, harvest and curing (Purseglove, 1992).

\subsection{Insect pests of onion}

Onion thrips, Thrips tabaci Lindeman (Thysanoptera: Thripidae) is a major pest of Allium crops (Lorbeer et al., 2002). Jones and Mann (1963) considered them to be the most severe pests of onions and their allies and attacks by thrips can totally destroy young plants. Jensen et al. (2003) considered T. tabaci to be the principal onion pest in eastern Oregon and Western Idaho (U.S.A.) where it can cause yield reductions by feeding on the epidermal cells of the plant, thus reducing the photosynthetic ability of the plant. T. tabaci reduce total yields by 4 to $27 \%$, depending on the onion variety, but can reduce yields of colossal sized bulbs by 28 to $73 \%$ (Jensen et al., 2002). No cultivar is resistant to thrips (mainly T. tabaci Lind. and Frankliniella schultzei Trybom) in the dry season or to Purple Blotch (Alternaria porri) in the wet season (Green, 1973).

\subsection{Control of onion thrips}

Shelton et al. (2003) noted that continued heavy reliance on lambda-cyhalothrin, and most likely other pyrethroids, would be problematic in New York onion fields. Other control options, such as cultural practices, 
should be encouraged but there are no thrips resistant onion cultivars or effective biological control measures that can be used on a reliable basis, other than the conservation of existing biological control through the use of minimal insecticide application. Therefore, this study was designed to

a) assess the effect of varying transplanting dates on thrips populations and onion bulb yield;

b) evaluate the optimum number of insecticide sprays for effective thrips reduction and

c) assess the combined effects of transplanting date and insecticide sprays on the incidence of thrips, their control and bulb yield.

\section{Materials and Methods}

\subsection{Experimental site}

Experiments were conducted at the Teaching and Research Farm of Usmanu Danfodiyo University, Sokoto situated at Kwalkwalawa, $5 \mathrm{~km}$ from the main campus of the University. Sokoto is located on latitude $13^{\circ} 01^{\prime} \mathrm{N}$ and longitude $05^{\circ} 15^{\prime} \mathrm{E}, 300 \mathrm{~m}$ above sea level. In 2000/2001 season, exploratory trials were conducted to identify the major insect pests of onion and in 2001/2002 and 2002/20003 seasons the main experiments were laid out in the field using Randomised Complete Block Design (RCBD). A local variety, Ex-Sokoto was raised in the nursery for eight weeks, before they were transplanted out by placing the seedlings into holes made with a sharp pointed stick at nearly the same depth they stood in the nursery. Poultry manure was applied before transplanting at the rate of $10 \mathrm{t} / \mathrm{ha}$. This was followed by application of $300 \mathrm{~kg} \mathrm{~N}$. P. K. at two weeks after transplanting (WAT) and $97.8 \mathrm{~kg} / \mathrm{ha}$ of urea $(46 \% \mathrm{~N})$ at 6 WAT. Two factors; date of planting/transplanting and frequency of insecticide sprays were investigated in a factorial arrangement using randomized complete block design (RCBD) replicated three times. Onion plants were transplanted into $2.5 \mathrm{~m}$ x1.5 m plots accommodating 5 rows of 17 plants/row. Spacing of $30 \mathrm{~cm}$ between and $15 \mathrm{~cm}$ within row was used.

\subsection{Planting and Transplanting}

The planting and transplanting dates were as follows:

\section{1/2002 season}

$\mathrm{P}_{1} 18 / 9 / 2001$

$\mathrm{P}_{2} 16 / 10 / 2001 ; 11 / 12 / 2001$

$\mathrm{P}_{3} 13 / 11 / 2001 ; 8 / 1 / 2002$

$\mathrm{P}_{4} \quad 11 / 12 / 2001 ; 5 / 2 / 2002$

$\mathrm{P}_{5} 8 / 1 / 2002 ; 5 / 3 / 2002$

\section{2/2003 season}

$17 / 9 / 2002 ; 12 / 11 / 2002$

$15 / 10 / 2002 ; 10 / 12 / 2002$

$12 / 11 / 2002 ; 7 / 1 / 2003$

$10 / 12 / 2002 ; \quad 4 / 2 / 2003$

$7 / 1 / 2003 ; 4 / 3 / 2003$

$\mathrm{P}_{6} 5 / 2 / 2002 ; 2 / 4 / 2002$

\subsection{Application of Treatments and sampling}

Insecticide application was the second factor investigated, in addition to the above. Spraying was done fortnightly starting from third week after transplanting using knapsack sprayer at the rate indicated below. Spray frequencies ranged from zero spray, which received no spray at all, to one spray made only once on the 1 spray plots; two sprays were given to plots marked for 2 sprays. Similar applications were made on three and four sprays, respectively. Two plants were selected by systematic sampling from $2^{\text {nd }}$ and $4^{\text {th }}$ rows at weekly intervals from each plot and excised plants were immediately placed in labeled polythene bags and later kept in a deep freezer. The choice of systematic sampling was to avoid sampling one plant twice, because onion plants usually regenerate. It was observed that on the November and December transplants it was difficult to distinguish between excised and un-sampled plants at 8-9 WAT and the only distinguishing feature was corrugation of leaves in the sampled plants.

Spraying was done with lambda-cyhalothrin (karate) $2.5 \%$ i.e. at $747 \mathrm{ml} / \mathrm{ha}(18.67 \mathrm{~g}$ a.i.) commencing from 3 WAT. This gave an equivalent of $40 \mathrm{ml}$ of karate in 20 litres of water. Drift to adjacent plots was controlled by the use of baft cloth screen which had four corners placed at each end of the plot. There was a waiting period of five minutes to allow the chemical to settle down before removing the screen. Yield data were obtained by 
harvesting the middle rows. The foliage was first removed with a knife before digging out the bulb with a large hoe.

\section{Results}

\subsection{Changes in Population of Onion Thrips}

In Table 1, at 4 WAT there was significant difference between treatments in their interaction as crops transplanted in November, December and January did not experience serious incidence of thrips in 2001/2002 and 2002/2003 seasons. One spray had reduced thrips population from 16 to 3.8 and 32.7 to 10.5 in the 2001/2002 and 2002/2003 seasons, respectively.

Significant differences were found in interactions between treatments at 6 and 7 WAT $(\mathrm{P}<0.01)$ (Table 2) in $2001 / 2002$ and at 6WAT in 2002/2003 seasons. Thrips population was found to increase from 169.5 to 456.3 per plant in one spray and have decreased in 0 spray, indicating that there was an upsurge in number of thrips due to new formed leaves requiring spray. The effect of 2 sprays was seen in 2002/2003 season where there was an increase in population of thrips from 26.3 to 190.7/plant (7WAT) after the effect of spray had subsided from 5-6 WAT. Third spray presented in Table 3 indicates that the number of thrips had increased when the effect of spray had ceased, where the number rose from 131.3 to 496.3 in 2001/2002 season in February plant and from 68.5 to 359 in 2002/2003 on January plant. The control plots had 352.8 as against the 3 spray plots with 68.5 in $2002 / 2003$ season. The effects of the insecticide sprays did not appear to last more than 7 days in the suppression of thrips population after they were applied whether in one, two or three sprays. The last or fourth spray was also found to be effective as there are less than 100 thrips /plant in the sprayed plot at 10 WAT in 2002/2003 season as compared to the control plots with 338.3 thrips/plant.

\subsection{Yield Data}

The yield data on the combined effects of dates of transplanting and insecticide spray frequencies are presented in Tables 5, 6, 7 and 8. In Table 5, there were no significant differences $(\mathrm{P}>0.05)$ in the mean number of bulbs/row in the different dates of transplanting and the different number of insecticide sprays. Table 6 shows that the mean wet weight of bulbs/row and mean weight of bulbs decreased with each date of transplanting in all the spray treatments in the two seasons (2001/2002 and 2002/2003), e.g.; in 2002/2003 season, the mean wet weight per row ranged from 0.12 to $3.75 \mathrm{~kg}$ and weight of individual bulbs varied from 11.0 to $268 \mathrm{~g}$. Clearly, early plantings/transplantings favoured the production of larger bulbs.

\subsection{Curing of Bulbs}

The mean cured weights of bulbs are presented in Table 7. The trend is similar to those described above in the Table 6 except that the values in Table 7 were lower than in Table 6 due to the loss of water from the bulbs during the curing period. Cured onion bulb yield in tons/ha in the unsprayed plots ranged from 0.83 in the March 5 transplanting of 2001/2002 season to 31.6 in the December 11 transplanting of the same season, while it ranged from 1.36 tons/ha in the March 4 transplanting of 2002/2003 season to 33.0 in the December and 46.4 in the November transplanting of the same season (Table 8). Clearly, early plantings/transplantings favoured higher yield as the highest yield of $60.4 \mathrm{t} / \mathrm{ha}$ was recorded in 3 sprays in November transplant. Generally, yields from plots sprayed with insecticide once were not better than those from the unsprayed plots (Table 6).

\section{Discussion}

It can be seen from the result that interaction had an effect on the number of thrips on onion (Table 1). The possible reason why the first insecticide spray and transplanting date did not have any effect on thrips numbers was perhaps due to low thrips population experienced in the field at that time, or the proportion of crops having thrips at that particular time. As expected, the effect of insecticide spray did not last more than 8-10 days. The second insecticide spray was surprisingly effective for two weeks in 2001/2002 season and lasted for just a week in 2002/2003 season.

Shelton et al. (1998) reported that onion varieties and insecticide application in combination significantly affected thrips damage, although their interaction was not significant. They observed that even frequent application of insecticides was not sufficient to keep thrips damage at acceptable levels and that planting tolerant varieties, was however a reliable way to keep thrips damage at low levels, even without insecticides. Patil et al. (1988) observed that the cultivars, which had a relatively wide angle of leaf emergence, had smaller population than those with a smaller angle and Soni and Ellis (1990) stated that resistance was found to be related to a wide angle of divergence of the two innermost leaves and the distance apart of the leaf blade on the sheath column. 
Ibrahim and Adesiyun (2009) found that less than 5thrips/plant were recorded on onion in January, but in February the population rose to 60 thrips/plant. Combining two or more methods agreed with Saxena (1975) who recommended a combination of resistant cultivars and releases of predators, where he observed that Chrysopa spp suppressed onion thrips population with judicious application of insecticides during peak period of infestations. In this study, two predators found were Exochomus flavipes Thunberg (Coleoptera: Coccinellidae) and Monolepta duplicata Chujo (Coleoptera: Chrysomelidae). They were found mostly in March in control plots, but not in sufficient number. Workman and Martin (2002) stated that natural enemies observed in the unsprayed and organic treatments included Ceranisus menes Walker, Aeolothrips fasciatum Linnaeus, Buhananiella whitei Reuter, syrphids and entomogenous fungi, Neozygites pavispora but none of them increased sufficiently to provide effective control of the pest. There are a number of natural enemies that help in the control of thrips; none of them alone can reduce thrips population to a low, non-economic density. Furthermore, the intensive use of pesticides in this crop limits natural enemy activity (Reuda and Shelton, 2003). Several natural enemies have been introduced to Hawaii in an attempt to help control this pest. However, only the parasite, C. menes, had become established (Mau and Kessing, 2000).

Several authors have recommended a combination of at least two factors, resistant variety with minimal chemical application or the above two plus biological control. But in this investigation a local variety planted at different times revealed that early transplanting without chemical application could produce good yield (Table 8). It also indicated that November transplant yielded $46 \mathrm{t} / \mathrm{ha}$, December transplant $33 \mathrm{t} / \mathrm{ha}$, after which there was heavy decline to $11 \mathrm{t} / \mathrm{ha}$. This showed that there was up to $29 \%$ reduction in yield between November and December transplants, and a further delay reduced the yield by $66 \%$ when December and January transplants were compared.

Looking at the control, one and two insecticide sprays in Table 8 , it indicate that there is a substantial increase in yield from 31.6 to $52.53 \mathrm{t} / \mathrm{ha}(40 \%)$ in the December transplant in 2001/2002 season, but in 2002/2003season, both the November and December transplants differed only slightly with the control with only $6 \%$ increase in yield in the two insecticide sprays. This is possibly because of either early invasion in the second year or perhaps the crop was relatively new in the area in 2001/2002 season and escaped attack. The highest yield of 60t/ha was in three sprays in 2002/2003 season. The effect of spray alone produced 27t/ha, Ibrahim and Adesiyun, (2007) and effect of planting alone 47.733t/ha, Ibrahim and Adesiyun, (2009). Similarly, on the cured bulb weight, there was a difference of up to $35 \%$ between the two insecticide sprays and the control in 2001/2002 season, and $32.3 \%$ between control and three sprays in the December transplant.

The control of thrips resulting in increasing onion yield has been reported. In Nigeria, Raheja, (1973) found that thrips damage may cause up to $41 \%$ loss in yield of onion bulbs and Uvah (1984) found increase of up to $32 \%$ in the insecticide treated plots when compared with the control, in Sudan Kisha (1977) stated that light infestations led to yield losses of at least $39 \%$, while severe thrips attack reduced onion crop yield by $57 \%$. Jensen et al. (2003) observed that the insect can reduce total onion yield from 4-27\%; Reuda and Shelton (2000) indicated that up to $66 \%$ loss might be caused by thrips. Also Mote (1978) observed that in India $50 \%$ of onion crops may be lost as a result of attack by thrips.

\section{Conclusion}

This study is in line with the global concern for de-emphasis on the use of chemicals; synthetic or otherwise. It showed that planting early is the best way to achieve higher yield of onion of over 40 t/ha by transplanting in November and using chemical karate $2.5 \mathrm{EC}$ increased the yield to $60.0 \mathrm{t} / \mathrm{ha}$. It was observed that any transplanting done beyond December will produce very low yield due to severe attack of thrips of 87.9 thrips/plant in 0 spray and 127.5 thripsplant in 1 spray at 7WAT.

\section{References}

Amans, E. B., Hussaini, M. A., \& Ramalan, A. A. (2000). Yield, bulb size distribution and storability of onion (Allium cepa L.) under different levels of N-fertilization and irrigation regime. Tropical Agriculture (Trinidad), 77 (3), 145-149.

Brice, J., Currah, L., Malius, A., \& Baucroft, R. (1997). Onion Storage in the Tropics: A Practical Guide to Methods of Storage and Their Selection, Chatham, U.K. Natural Resource Institute. 120 pp.

Green, J. H. (1973). Cultivar Trials with onion (Allium cepa L.) in the northern states of Nigeria. Nigerian Agricultural Journal, 8(2), 169-174.

Ibrahim, N.D., \& A. A. Adesiyun. (2007). Control of Thrips tabaci Lindeman (Thysanoptera: Thripidae) on onion (Allium cepa) in Sokoto, Nigeria. Nigerian Journal of Entomology, 24, 82-90. 
Ibrahim, N.D., \& A. A. Adesiyun. (2009). Effects of staggered planting dates on the control of Thrips tabaci Lindeman and yield of onion in Nigeria. African Journal of Agricultural Research, 4 (1), 033-039.

Jensen, L., Simko, B., Shock, C. C., \& Saunders, L. D. (2003). A two-year study on alternative methods for controlling onion thrips (Thrips tabaci L.) in Spanish onions. Oregon State University Agricultural Experiment Station Special Report, 1048, 94-106.

Jensen, L., Simko, B., Shock, C. C., \& Saundres, L. D. (2002). Alternative methods for controlling onion thrips (Thrips tabaci) in Spanish onions. Oregon State University Agricultural Experiment Station Special Report, 1038, 104-111.

Jones, H. A., \& Mann, L. K. (1963). Onions and their Allies, Botany, Cultivation and utilization. Leonard Hill Inter-Science, London. 286 pp.

Kisha, J. S. A. (1977). Cultural and insecticidal control of Thrips tabaci on onions in the Sudan. Annals of Applied Biology, 86, $219-228$.

Lorbeer, J. W., Kuhar, T. P., \& Hoffmann, M. P. (2002). Monitoring and forecasting for Disease and Insect Attack in Onions and Allium crops within IPM strategies. In: Rabinowitch, H.D. and Currah, L. (Eds). Allium Crop Science: Recent Advances, (pp. 293-309). CABI, Wallingford, U.K.

Mau, R. F. L., \& Kessing, J. L. M. (2000). Thrips tabaci L. crop knowledge master. [Online] Available http://www.extento.hawaii.edu/kbase/crop/type/t_tabaci.htm (August 15, 2000).

Mote, M. (1978). Control of onion thrips (Thrips tabaci (L.). Pesticides 12, 42.

Patil, A. P., Nawale, R. N., Ajir, D. S., \& Moholkar, P. R. (1988). Field screening of onion cultivars for reaction to thrips. Indian Cocoa, Arecanut and spices Journal, 12 (1), 10-11.

Purseglove, J. W. (1992). Tropical Crops: Monocotyledon, Revised edition. Longman Scientific and Technical, U.K. 607 pp.

Raheja, A. K. (1973). Onion Thrips and their control in northern Nigeria. Samaru Agricultural Newsletter, 15(2), $82-86$.

Reuda, A., \& Shelton, A. M. (2000). Onion thrips. [Online] Available: http://www. nysaes.cornell.edu/ent/hortcrops/english/thrips.html (July10, 2000).

Reuda, A., \& Shelton, A. M. (2003). Development of a bioassay system for monitoring susceptibility in Thrips tabaci. Pest Management, 59 (5), 553-558.

Saxena, R. C. (1975). Integrated approach for the control of Thrips tabaci Lindeman. Indian Journal of Agricultural Science, 45, $434-436$.

Shelton, A. M., Nault, B. A., Plate, J., \& Zhao, Z. J. (2003). Regional and temporal variation in susceptibility to lambda-cyhalothrin in onion Thrips, Thrips tabaci (Thysanoptera: Thripidae) in onion fields in New York. Journal of Economic Entomology, 96 (6), 1843-1848.

Shelton, A. M., Wilsey, W. T., \& Schmaedick, M. A. (1998). Management of onion thrips (Thysanoptera: Thripide) on cabbage by using plant resistance and insecticides. Journal of Economic Entomology, 91 (1), 329-333.

Soni, S. K., \& Ellis, P. R. (1990). Insect pests. In: Rabinowitch, H.D. and Brewster, J.L. (Eds). Onions and Allied Crops, 213 -271, Vol. II Agronomy, Biotic interactions, Pathology, and Crop Protection CRC press, Boca Raton, Florida, USA II..

Uvah, I. I. (1984). Studies on the control of onion thrips, Thrips tabaci L. on irrigated onion at Zaria. Nigerian Entomological Magazine, 4 (2), 74-77.

Workman, P. J., and Martin, N. A. (2002). Towards integrated pest management of Thrips tabaci in onions. New Zealand Plant Protection, 55, $188-192$. 
Table 1. Combined effects of date of transplanting and frequency of insecticidal sprays on thrips population at 4 and 5 weeks after transplanting (WAT) in 2001/2002 and 2002/2003 seasons

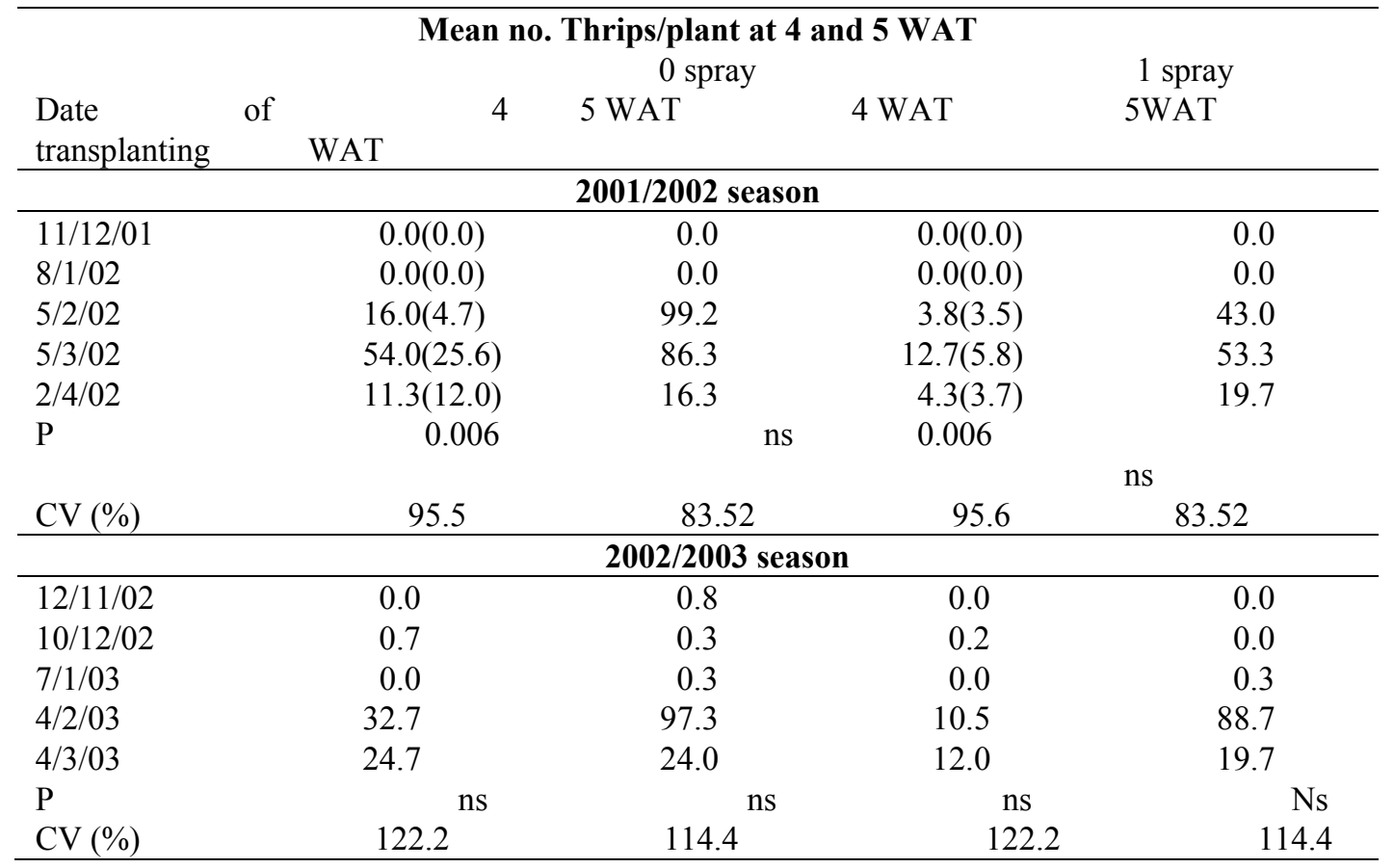

ns $=$ not significant

values in bracket are the standard deviation(SD) and dividing by $5(\sqrt{ } 25)$ gives standard error $( \pm \mathrm{SE})$

Table 2. Combined effects of date of transplanting and frequency of insecticidal sprays on thrips population at 6 and 7 weeks after transplanting (WAT) in 2001/2002 and 2002/2003 seasons

\begin{tabular}{|c|c|c|c|c|c|c|}
\hline \multicolumn{7}{|c|}{ Mean no. Thrips/plant at 6 and 7 WAT } \\
\hline \multirow[b]{2}{*}{$\begin{array}{c}\text { Date of } \\
\text { Transplanting }\end{array}$} & \multicolumn{2}{|c|}{0 spray } & \multicolumn{2}{|c|}{1 spray } & \multicolumn{2}{|c|}{2 sprays } \\
\hline & $6 \mathrm{WAT}$ & $7 \mathrm{WAT}$ & $6 \mathrm{WAT}$ & $7 \mathrm{WAT}$ & $6 \mathrm{WAT}$ & 7 WAT \\
\hline \multicolumn{7}{|c|}{$2001 / 2002$ season } \\
\hline $11 / 12 / 01$ & $0.0(0.0)$ & $0.0(0.0)$ & $0.0(0.0)$ & $0.0(0.0)$ & $0.0(0.0)$ & $1.7(2.4)$ \\
\hline $8 / 1 / 02$ & $5.3(5.0)$ & $11.7(9.0)$ & $2.8(0.5)$ & $17.7(9.3)$ & $2.2(1.1)$ & $16.5(3.12)$ \\
\hline $5 / 2 / 02$ & $148.2(69.4)$ & $128.7(153.0)$ & $169.5(62.5)$ & $456.3(172.5)$ & $105.8(23.2)$ & $195.3(39.8)$ \\
\hline $5 / 3 / 02$ & $9.0(8.7)$ & $11.0(3.6)$ & $17.0(7.5)$ & $19.0(17.5)$ & 20.3(10.9) & $3.7(3.2)$ \\
\hline $2 / 4 / 02$ & $0.3(0.5)$ & $0.0(0.0)$ & $3.0(2.6)$ & $0.0(0.0)$ & $6.0(2.1)$ & $0.0(0.0)$ \\
\hline $\mathrm{P}$ & 0.0002 & 0.0001 & 0.0002 & 0.0001 & 0.0002 & 0.0001 \\
\hline $\mathrm{CV}(\%)$ & 79.9 & 96.7 & 79.9 & 96.7 & 79.9 & 96.7 \\
\hline \multicolumn{7}{|c|}{$2002 / 2003$ season } \\
\hline $12 / 11 / 02$ & $0.0(0.0)$ & 1.8 & $0.0(0.0)$ & 0.2 & $0.5(0.5)$ & 0.0 \\
\hline $10 / 12 / 02$ & $1.8(2.0)$ & 5.7 & $0.0(0.0)$ & 0.3 & $0.0(0.0)$ & 0.5 \\
\hline 7/1/03 & $1.3(1.0)$ & 87.9 & $2.8(0.2)$ & 127.5 & $2.2(2.1)$ & 45.0 \\
\hline $4 / 2 / 03$ & $170.0(27.4)$ & 98.3 & $232.0(102.0)$ & 95.0 & $26.3(26.3)$ & 190.7 \\
\hline $4 / 3 / 03$ & $47.7(51.2)$ & 64.7 & $77.3(73.2)$ & 29.0 & $19.0(13.0)$ & 51.0 \\
\hline $\mathrm{P}$ & 0.0001 & ns & 0.0001 & ns & 0.0001 & ns \\
\hline $\mathrm{CV}(\%)$ & 98.7 & 00.9 & 98.7 & 100.9 & 98.7 & 100.9 \\
\hline
\end{tabular}

ns $=$ not significant

values in bracket are the standard deviation(SD) and dividing by $5(\sqrt{ } 25)$ gives standard error $( \pm \mathrm{SE})$ 
Table 3. Combined effects of date of transplanting and insecticidal sprays on thrips population at 8 and 9 weeks after transplanting (WAT) in 2001/2002 and 2002/2003 seasons

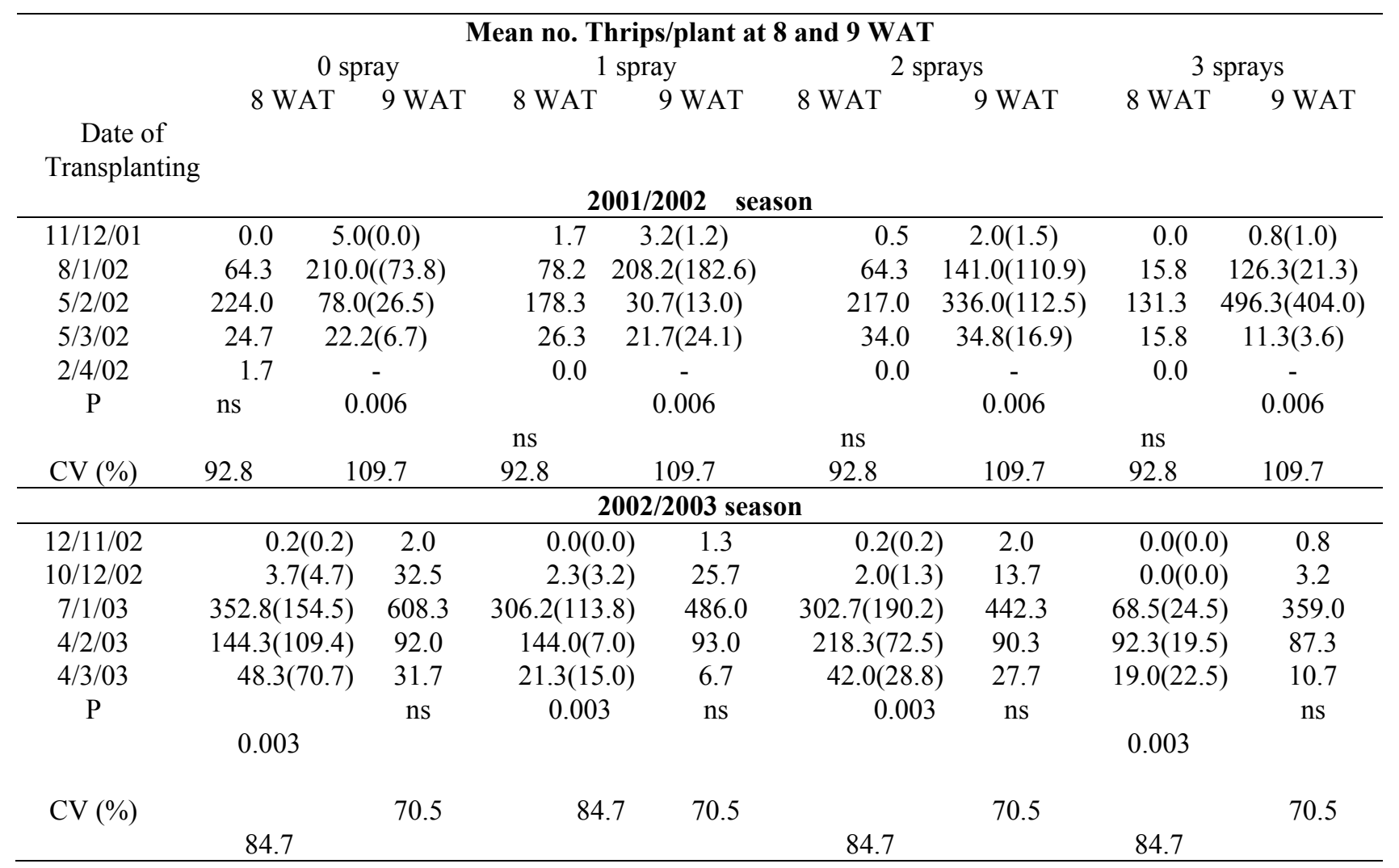

ns $=$ not significant

values in bracket are the standard deviation(SD) and dividing by $5(\sqrt{25})$ gives standard error $( \pm \mathrm{SE})$ 
Table 4. Combined effects of date of transplanting and four insecticide sprays on thrips population at 10 and 11 weeks after transplanting (WAT) in 2001/2002 and 2002/2003 seasons

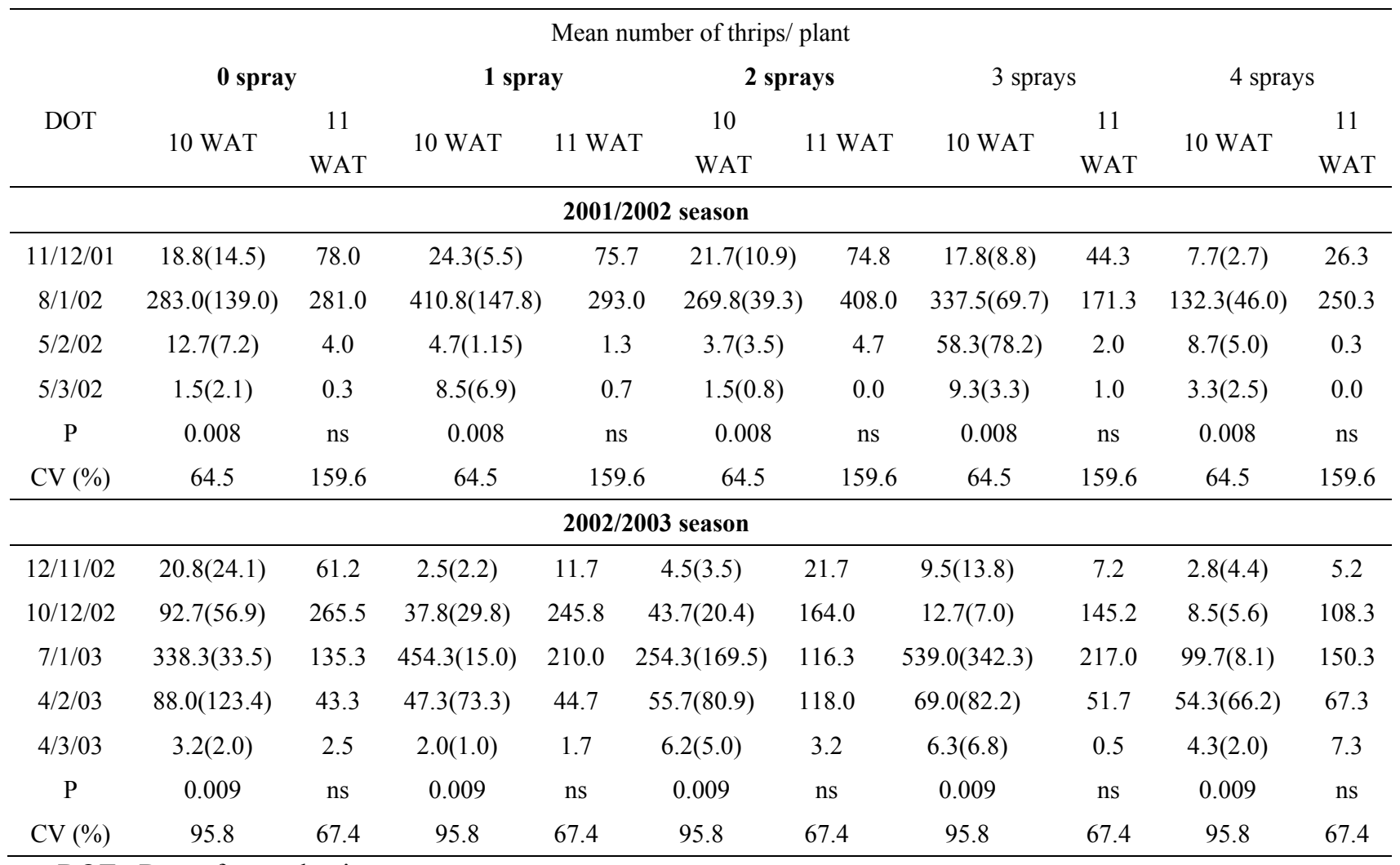

DOT= Date of transplanting

ns $=$ not significant

values in bracket are the standard deviation(SD) and taking their square root gives standard error $( \pm \mathrm{SE})$

Table 5. Combined effects of date of transplanting and frequency of insecticidal spray on number of onion bulbs/row of onion in 2001/2002 and 2002/2003 seasons

\begin{tabular}{l|l|l|l|l|l}
\hline \multicolumn{1}{c|}{$\begin{array}{c}\text { Date of } \\
\text { transplanting }\end{array}$} & 0 spray & 1 spray & 2 sprays & 3 sprays & 4 sprays \\
\hline \multicolumn{5}{c}{$\mathbf{2 0 0 1 / 2 0 0 2}$ season } \\
\hline $11 / 12 / 01$ & 15.3 & 17.7 & 16.7 & 15.7 & 14.3 \\
$8 / 1 / 02$ & 14.7 & 13.3 & 14.7 & 13.7 & 17.0 \\
$5 / 2 / 02$ & 11.7 & 12.7 & 12.0 & 12.0 & 13.7 \\
$5 / 3 / 02$ & 5.0 & 6.7 & 8.3 & 6.0 & 6.7 \\
$\mathrm{P}$ & $\mathrm{ns}$ & $\mathrm{ns}$ & $\mathrm{ns}$ & $\mathrm{ns}$ & $\mathrm{ns}$ \\
$\mathrm{CV}(\%)$ & 15.95 & 15.95 & 15.95 & 15.95 & 15.95 \\
\hline \multicolumn{7}{c}{$\mathbf{2 0 0 2 / 2 0 0 3}$ season } \\
\hline $12 / 11 / 02$ & 14.0 & 13.0 & 14.7 & 16.0 & 12.0 \\
$10 / 12 / 02$ & 16.0 & 17.0 & 17.0 & 17.0 & 16.0 \\
$7 / 1 / 03$ & 13.3 & 13.3 & 13.0 & 12.7 & 11.7 \\
$4 / 2 / 03$ & 14.7 & 12.8 & 13.0 & 13.3 & 11.3 \\
$4 / 3 / 03$ & 10.7 & 11.0 & 12.7 & 10.3 & 10.3 \\
$\mathrm{P}$ & $\mathrm{ns}$ & $\mathrm{ns}$ & $\mathrm{ns}$ & $\mathrm{ns}$ & $\mathrm{ns}$ \\
$\mathrm{CV}(\%)$ & 16.01 & 16.01 & 16.01 & 16.01 & 16.01 \\
\hline
\end{tabular}

ns $=$ not significant 
Table 6. Combined effects of dates of transplanting and insecticide spray frequencies on wet weight of onion bulbs in 2001/2002 and 2002/2003 seasons

\begin{tabular}{|c|c|c|c|c|c|c|c|c|c|c|}
\hline \multirow{3}{*}{$\begin{array}{l}\text { Dates of } \\
\text { transplanting }\end{array}$} & \multicolumn{2}{|l|}{0 spray } & \multicolumn{2}{|l|}{1 spray } & \multicolumn{2}{|l|}{2 sprays } & \multicolumn{2}{|l|}{3 sprays } & \multicolumn{2}{|l|}{4 sprays } \\
\hline & \multicolumn{10}{|c|}{ Mean wet weight } \\
\hline & $\mathrm{Kg} /$ row & $\mathrm{g} / \mathrm{bulb}$ & $\mathrm{Kg} /$ row & $\mathrm{g} / \mathrm{bulb}$ & $\mathrm{Kg} /$ row & $\mathrm{g} / \mathrm{bulb}$ & $\mathrm{Kg} /$ row & $\mathrm{g} / \mathrm{bulb}$ & $\mathrm{Kg}$ /row & $\mathrm{g} / \mathrm{bulb}$ \\
\hline & \multicolumn{10}{|c|}{ 2001/2002 season } \\
\hline \multirow[t]{2}{*}{$11 / 12 / 01$} & 2.47 & 161.00 & 3.39 & 191.00 & 4.08 & 247.00 & 2.53 & 160.00 & 3.07 & 213.00 \\
\hline & $(0.6)$ & $(0.02)$ & $(0.4)$ & $(0.02)$ & $(0.9)$ & $(0.05)$ & $(0.8)$ & $(0.04)$ & $(0.7)$ & $(0.007)$ \\
\hline \multirow[t]{2}{*}{$8 / 1 / 02$} & 0.80 & 54.00 & 0.79 & 59.00 & 1.33 & 77.00 & 1.61 & 118.00 & 1.81 & 108.00 \\
\hline & $(0.2)$ & $(0.007)$ & $(0.2)$ & $(0.01)$ & $(0.2)$ & $(0.01)$ & $(0.07)$ & $(0.006)$ & $(0.3)$ & $(0.02)$ \\
\hline \multirow[t]{2}{*}{$5 / 2 / 02$} & 0.27 & 22.00 & 0.39 & 30.00 & 0.50 & 41.00 & 0.55 & 48.00 & 0.57 & 42.00 \\
\hline & $(0.1)$ & $(0.007)$ & $(0.1)$ & $(0.005)$ & $(0.2)$ & $(0.01)$ & $(0.1)$ & $(0.01)$ & $(0.09)$ & $(0.008)$ \\
\hline \multirow[t]{2}{*}{$5 / 3 / 02$} & 0.07 & 15.00 & 0.12 & 18.00 & 0.12 & 14.00 & 0.09 & 14.00 & 0.11 & 13.00 \\
\hline & $(0.03)$ & $(0.01)$ & $(0.06)$ & $(0.01)$ & $(0.02)$ & $(0.002)$ & $(0.06)$ & $(0.006)$ & $(0.08)$ & $(0.009)$ \\
\hline$P$ & 0.003 & 0.001 & 0.003 & 0.001 & 0.003 & 0.001 & 0.003 & 0.001 & 0.003 & 0.001 \\
\hline \multirow[t]{2}{*}{ CV (\%) } & 32.0 & 25.2 & 32.0 & 25.2 & 32.0 & 25.2 & 32.0 & 25.2 & 32.0 & 25.2 \\
\hline & \multicolumn{10}{|c|}{ 2002/2003 season } \\
\hline $12 / 11 / 02$ & 3.75 & 268.00 & 3.39 & 266.00 & 3.93 & 270.00 & 4.78 & 297.00 & 3.17 & 265.00 \\
\hline $10 / 12 / 02$ & 2.78 & 174.00 & 3.48 & 205.00 & 3.14 & 184.00 & 4.10 & 242.00 & 3.92 & 245.00 \\
\hline 7/1/03 & 0.95 & 71.00 & 0.95 & 73.00 & 0.83 & 64.00 & 1.17 & 92.00 & 0.93 & 80.00 \\
\hline $4 / 2 / 03$ & 0.70 & 47.00 & 0.45 & 36.00 & 0.57 & 44.00 & 0.60 & 44.00 & 0.38 & 33.00 \\
\hline $4 / 3 / 03$ & 0.12 & 11.00 & 0.1 & 8.00 & 0.16 & 12.00 & 0.20 & 17.00 & 0.13 & 12.00 \\
\hline $\mathrm{P}$ & ns & ns & ns & ns & ns & ns & ns & ns & $\mathrm{ns}$ & $\mathrm{ns}$ \\
\hline CV (\%) & 25.2 & 19.4 & 25.2 & 19.4 & 25.2 & 19.4 & 25.2 & 19.4 & 25.2 & 19.4 \\
\hline
\end{tabular}

ns $=$ not significant

values in bracket are the standard deviation(SD) and dividing by $5(\sqrt{ } 25)$ gives standard error $( \pm \mathrm{SE})$ 
Table 7. Combined effects of dates of transplanting and insecticide spray frequencies on cured weight of onion bulbs in 2001/2002 and 2002/2003 seasons

\begin{tabular}{|c|c|c|c|c|c|c|c|c|c|c|}
\hline \multirow{3}{*}{$\begin{array}{c}\text { Dates of } \\
\text { transplanting }\end{array}$} & \multicolumn{2}{|c|}{0 spray } & \multicolumn{2}{|c|}{1 spray } & \multicolumn{2}{|c|}{2 sprays } & \multicolumn{2}{|c|}{3 sprays } & \multicolumn{2}{|c|}{4 sprays } \\
\hline & \multicolumn{10}{|c|}{ Mean cured weight } \\
\hline & $\mathrm{Kg} /$ row & $\mathrm{g} / \mathrm{bulb}$ & $\mathrm{Kg} /$ row & $\mathrm{g} / \mathrm{bulb}$ & $\mathrm{Kg} /$ row & $\mathrm{g} / \mathrm{bulb}$ & $\mathrm{Kg}$ /row & $\mathrm{g} / \mathrm{bulb}$ & $\mathrm{Kg} /$ row & $\mathrm{g} / \mathrm{bulb}$ \\
\hline & \multicolumn{10}{|c|}{ 2001/2002 season } \\
\hline $1 / 12 / 01$ & 2.37 & 155.00 & 3.28 & 185.00 & 3.94 & 238.00 & 2.24 & 140.00 & 2.99 & 208.00 \\
\hline 11712700 & $(0.64)$ & $(0.02)$ & $(0.38)$ & $(0.01)$ & $(0.8)$ & $(0.05)$ & $(1.0)$ & $(0.05)$ & $(0.72)$ & $(0.007)$ \\
\hline $8 / 1 / 07$ & 0.73 & 49.00 & 0.65 & 47.00 & 1.05 & 71.00 & 1.48 & 109.00 & 1.70 & 101.00 \\
\hline $0 / 1 / 02$ & $(0.23)$ & $(0.009)$ & $(0.27)$ & $(0.01)$ & $(0.2)$ & $(0.009)$ & $(0.07)$ & $(0.02)$ & $(0.35)$ & $(0.02)$ \\
\hline $5 / 2 / 02$ & 0.21 & 18.00 & 0.32 & 25.00 & 0.43 & 35.00 & 0.49 & 42.00 & 0.49 & 37.00 \\
\hline (1) & $(0.07)$ & $(0.004)$ & $(0.1)$ & $(0.04)$ & $(0.2)$ & $(0.01)$ & $(0.1)$ & $(0.01)$ & $(0.06)$ & $(0.06)$ \\
\hline $5 / 2 / 07$ & 0.06 & 14.00 & 0.11 & 17.00 & 0.11 & 14.00 & 0.08 & 12.00 & 0.10 & 12.00 \\
\hline (2/ & $(0.04)$ & $(0.01)$ & $(0.06)$ & $(0.01)$ & $(0.02)$ & $(0.001)$ & $(0.05)$ & $(0.006)$ & $(0.08)$ & $(0.09)$ \\
\hline $\mathrm{P}$ & 0.003 & 0.0006 & 0.003 & 0.0006 & 0.003 & 0.0006 & 0.003 & 0.0006 & 0.003 & 0.0006 \\
\hline \multirow[t]{2}{*}{ CV (\%) } & 35.6 & 27.6 & 35.6 & 27.6 & 35.6 & 27.6 & 35.6 & 27.6 & 35.6 & 27.6 \\
\hline & \multicolumn{10}{|c|}{$2002 / 2003$ season } \\
\hline $12 / 11 / 02$ & $\begin{array}{c}3.48 \\
(0.58)\end{array}$ & 249.00 & $\begin{array}{c}3.21 \\
(0.48)\end{array}$ & 252.00 & $\begin{array}{c}3.71 \\
(0.19)\end{array}$ & 254.00 & $\begin{array}{c}4.53 \\
(0.95)\end{array}$ & 281.00 & $\begin{array}{c}2.96 \\
(1.08)\end{array}$ & 247.00 \\
\hline $10 / 12 / 02$ & $\begin{array}{c}2.47 \\
(0.63)\end{array}$ & 155.00 & $\begin{array}{c}3.31 \\
(0.58)\end{array}$ & 195.00 & $\begin{array}{c}2.99 \\
(0.48)\end{array}$ & 176.00 & $\begin{array}{c}3.89 \\
(0.48)\end{array}$ & 229.00 & $\begin{array}{c}3.74 \\
(0.35)\end{array}$ & 234.00 \\
\hline $7 / 1 / 03$ & $\begin{array}{c}0.84 \\
(0.37)\end{array}$ & 62.00 & $\begin{array}{c}0.89 \\
(0.16)\end{array}$ & 68.00 & $\begin{array}{c}0.76 \\
(0.26)\end{array}$ & 57.00 & $\begin{array}{c}1.07 \\
(0.280\end{array}$ & 84.00 & $\begin{array}{c}0.80 \\
(0.27)\end{array}$ & 68.00 \\
\hline $4 / 2 / 03$ & $\begin{array}{c}0.61 \\
(0.19)\end{array}$ & 41.00 & $\begin{array}{c}0.37 \\
(0.13)\end{array}$ & 30.00 & $\begin{array}{c}0.49 \\
(0.04)\end{array}$ & 38.00 & $\begin{array}{c}0.53 \\
(0.25)\end{array}$ & 39.00 & $\begin{array}{c}0.33 \\
(0.04)\end{array}$ & 30.00 \\
\hline $4 / 3 / 03$ & $\begin{array}{c}0.10 \\
(0.03)\end{array}$ & 9.00 & $\begin{array}{c}0.08 \\
(0.01)\end{array}$ & 7.00 & $\begin{array}{c}0.13 \\
(0.06)\end{array}$ & 10.00 & $\begin{array}{c}0.17 \\
(016)\end{array}$ & 14.00 & $\begin{array}{c}0.10 \\
(0.05)\end{array}$ & 10.00 \\
\hline $\mathrm{P}$ & 0.03 & ns & 0.03 & ns & 0.03 & ns & 0.03 & ns & 0.03 & ns \\
\hline CV (\%) & 25.8 & 19.8 & 25.8 & 19.8 & 25.8 & 19.8 & 25.8 & 19.8 & 25.8 & 19.8 \\
\hline
\end{tabular}

ns $=$ not significant

values in bracket are the standard deviation(SD) and dividing by $5(\sqrt{ } 25)$ gives standard error $( \pm \mathrm{SE})$ 
Table 8. Combined effects of dates of transplanting and insecticide spray frequencies on the cured bulb yield of onions in tons/ha in 2001/2002 and 2002/2003 seasons

\begin{tabular}{|c|c|c|c|c|c|}
\hline \multirow[t]{2}{*}{$\begin{array}{l}\text { Date of } \\
\text { Transplanting }\end{array}$} & 0 spray & 1 spray & 2 sprays & 3 sprays & 4 sprays \\
\hline & \multicolumn{5}{|c|}{ Mean cured weight of bulbs (tons/ha) } \\
\hline \multicolumn{6}{|c|}{ 2001/2002 season } \\
\hline $11 / 12 / 01$ & $31.60(8.5)$ & $43.77(5.1)$ & 52.53(11.5) & 29.91(13.8) & $39.91(9.7)$ \\
\hline $8 / 1 / 02$ & $9.73(3.0)$ & $8.67(3.7)$ & $14.00(2.6)$ & $19.78(1.0)$ & $22.67(4.6)$ \\
\hline $5 / 2 / 02$ & $2.84(1.0)$ & $4.22(1.3)$ & $5.78(3.0)$ & $6.58(1.3)$ & $6.58(0.8)$ \\
\hline $5 / 3 / 02$ & $0.83(0.5)$ & $1.49(0.9)$ & $1.48(0.2)$ & $1.08(0.7)$ & $1.36(1.1)$ \\
\hline $\mathrm{P}$ & 0.003 & 0.003 & 0.003 & 0.003 & 0.003 \\
\hline CV (\%) & 35.6 & 35.6 & 35.6 & 35.6 & 35.6 \\
\hline \multicolumn{6}{|c|}{$2002 / 2003$ season } \\
\hline $12 / 11 / 02$ & $46.44(7.7)$ & $42.85(6.4)$ & $49.47(2.5)$ & $60.40(12.7)$ & $39.51(14.5)$ \\
\hline $10 / 12 / 02$ & $32.98(8.4)$ & $44.09(7.7)$ & $39.91(6.4)$ & $51.82(6.4)$ & $49.87(4.7)$ \\
\hline 7/1/03 & $11.20(4.9)$ & $11.91(2.2)$ & $10.09(3.4)$ & $14.22(3.7)$ & $10.62(3.6)$ \\
\hline $4 / 2 / 03$ & $8.09(2.6)$ & $4.93(1.8)$ & $6.53(0.6)$ & $7.11(3.4)$ & $4.44(0.5)$ \\
\hline $4 / 3 / 03$ & $1.36(0.4)$ & $1.06(0.2)$ & $1.69(0.8)$ & $2.21(2.2)$ & $1.40(0.7)$ \\
\hline $\mathrm{P}$ & 0.03 & 0.03 & 0.03 & 0.03 & 0.03 \\
\hline CV (\%) & 25.9 & 25.9 & 25.9 & 25.9 & 25.9 \\
\hline
\end{tabular}

values in bracket are the standard deviation(SD) and dividing by $5(\sqrt{ } 25)$ gives standard error $( \pm \mathrm{SE})$ 